\title{
University of Queensland
}

\author{
Susan Sullivan
}

\section{The quest for tourism authenticity: The mediation and appropriation of literary- induced tourism}

\begin{abstract}
:
Authenticity is a much-debated concept across fields as diverse as tourism to philosophy. In the tourism and travel arena, authenticity is primarily viewed through the lens of the tourist rather than the experience of the travel writer. One way in which existential authenticity is realised in tourism experiences is through the evocation of feelings, emotions and states of being in both travel communication and the actual tourism activity. This article looks at how themes from literature and subsequent adaptions into popular culture via film and television are appropriated by tourism communicators to portray an authentic tourism experience. It will examine examples of tourist locations that are appropriated and mediated into literarybased storytelling by travel writers in order to attract visitors. These case studies include the adoption of Tolkien in New Zealand and Shakespeare in Italy. The article also considers how these inter-media adaptations transform and extend the shelf-life of tourism communication campaigns.
\end{abstract}

\section{Biographical note:}

Susan Sullivan is a $\mathrm{PhD}$ candidate at the University of Queensland. She has worked in tourism public relations for more than 30 years in senior public relations roles at Hamilton Island and Mantra Group and in a consultancy role for tourism operators including Aspen Skiing Company, Sunsail, Royal Pines Resort, Lake Crackenback Resort \& Spa and Ocean Blue Oman, among others. For the past 16 years, Susan has worked in parallel to her professional career as a sessional academic at Griffith University, Bond University and most recently the University of Queensland.

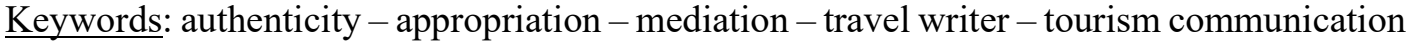


Dear Juliet,

I am no longer young, but there was a time, yes, there was a time when I believed in love. I can sound out the names of lovers and draw up their faces, each one, so clearly. And then they are gone. Why is it that love comes so easily for some but refuses to stay for others? Why should it be so? Why should it twist our souls so grievously?

\section{Introduction}

This letter arrived in an envelope, simply addressed to Juliet, Verona, Italy. The Juliet it was sent to - larger than life in Shakespeare's pages - does not exist at any fixed address. The letter is one of approximately 50,000 lovelorn letters received each year by a group known as 'Secretaries of Juliet', volunteers who celebrate Juliet's 'literary, not literal existence' (Squires 2010: 1). The Italian city of Verona, the self-declared 'city of love', has attracted tourists for decades based on Shakespeare's Romeo and Juliet. The story, written in the $1500 \mathrm{~s}$, has been popularised in modern times through various adaptations including the 2010 movie Letters to Juliet which chronicles a search for love through the tradition of people writing a letter about their woes of love to Shakespeare's fictional character Juliet. Since 1932, the volunteers have responded to each letter, 'in the name of the most famous heroine in literature keeping alive this extraordinary epistolary tradition' (Juliet Club 2018).

The handwritten personal response triggers an emotional response for the recipient, notwithstanding Juliet's fictional character. Instead, the legitimacy of the reply validates the feeling of connection to the essence of Juliet in a way that might be anticipated by someone imagining how Juliet would respond - if in fact she was real. Chaney likens this to 'laminations of reality' (2002: 197), where people are blissful in the dramaturgy of what they interpret as real and true despite it being at odds with factual reality.

Reijnders argues that characters, storyline and location of books, movies and television, can motivate tourism because they spark imagination that immerses the audience in another place or state of mind; evoking emotions, familiarity and relatability which can be physically re-lived and re-created (2011:105). The power of imagination can be sparked by a literary storyline as a trigger, motivating tourists on a pilgrimage. As such they can escape into a fantasy world where passive readers transform into active tourists who seek to bring the plot, characters and a story's location into their own experience (Riley \& Van Doren 1992: 268). The tourism industry successfully leverages literary work into real and lived experiences that can be touched, tasted, smelled, seen, heard and felt. Eckhardt VoigtsVirchnow notes the physical nature of tourism means that 'texts become objects not just to read but to reckon with, to be moved around, to delight and wallow in' (2012: 39).

This article will look at how the tourism industry brings literature to life as commoditised tourism products, with tourism communicators appropriating stories and characters originally popularised by literary, televisual and cinematic means as a basis for destination promotion. As part of the promotional process, these stories are mediatised by travel writers 
to help potential visitors connect with a tourism location. By examining examples of literary-induced tourism, we will see the role of these inter-media adaptations as markers of whether or not tourists deem their experience as authentic.

Throughout this work, I use the term tourism communicator to describe a person working in a public relations or communication role within a tourism organisation while references to travel media, travel writers and journalists are used interchangeably in the context that these people are assuming the role of quasi-tourist. And, while there is considerable scholarly debate about the difference between a tourist, traveller and visitor, I will take a homogenous approach and consider tourism as defined by the United Nations World Tourism Organisation (UNWTO 2018) as 'the activities of persons traveling to and staying in places outside their usual environment for not more than one consecutive year for leisure, business and other purposes'. This definition is simplified further for this article by considering tourists as those who visit a location for a short time for the purpose of leisure.

\section{Tourism and authenticity}

While there is much scholarly literature surrounding the authenticity of a tourism experience from a tourist's perspective, little addresses the role tourism communicators and travel media play in framing the authenticity of a location. For it is the perception of authenticity that defines the difference between bland and memorable tourism experiences (Pine \& Gilmore 2007: 62), while understanding authenticity has been described by Erler as a theoretical stalemate where 'one person's authenticity is another's betrayal' (2012: 257). There are many ways of looking at the concept of authenticity, but this paper will review some of the major schools of thought in relation to tourism communication.

From the 1970 s the tourism industry recognised, and widely accepted, the concept of staged authenticity, where tourism experiences are created and crafted to meet tourist needs (MacCannell 1973: 590). Staged authenticity involves two interrelated types of staging: 'substantive staging' where an attraction is altered or created to suit tourism needs and 'communicative staging' where authenticity is articulated via tourism promotion (Cohen 1988: 383; MacCannell 1973: 598). With a general acceptance that staged authenticity is central to tourism, Wang developed this distinction, describing three types of authenticity in tourism; objective authenticity (whether something is real or not), constructive authenticity (when something is purpose built to look authentic), and existential authenticity (the feelings, emotions and state of being evoked from a tourism experience) (1999: 352).

Adding to the complexity, the emotions and sense-of-self garnered through existential authenticity may be considered alongside the idea of relational authenticity, where interpersonal relationships and interactions of the tourism experience contribute to the perception of authenticity (Fletcher 2013: 84). For example, one company, offers a tour called 'On the Tracks of 007' (2019) to mark the 50 th anniversary of the 1969 movie On Her Majesty's Secret Service adapted from Ian Fleming's 1963 novel of the same name. As an example of staged authenticity, tourists can visit Piz Gloria on the top of the 
Schilthorn in Switzerland, to meet George Lazenby, the James Bond of the time, and other cast members, be entertained by a James Bond tribute band as well as walk through the tourist attractions of Piz Gloria including Bond World and Walk of Fame (ibid). The authenticity of this tour will be determined by the individual visitors. Some James Bond enthusiasts may revel in the opportunity to visit Bond World and do the walk of fame (constructive authenticity), while others will seek an adventure-charged adrenaline rush and immerse themselves in the storyline as if they were actually James Bond (existential authenticity). Being surrounded by like-minded fans (relational authenticity) bolsters the depth of authenticity as aspects of the experience, the book and the film are collectively shared and discussed.

The perception of authenticity does not come solely from the tourism experience, but also how it stems back to memories of when and where the visitor saw the movie or read the book (Reijnders 2011: 113). Memories of that moment in time, along with the visitor's recollection of their youth, can influence the perceived authenticity of the tourism experience together with the physical attributes of the tourist attraction/destination.

Such feelings may be traced back to ancient Greek philosophical notions of authenticity shrouded in injunctions to 'know thyself' and 'to thine own self be true' which Hartner (2005: 352) recognises as personal experiences, thoughts and emotions; demonstrating that existential authenticity is highly individual and generally intangible. Existentialist authenticity, as a state of being, therefore sees less importance placed on the historical accuracy of a tourism activity than how the tourism experience makes people feel (Arnould and Price 2000: 141). This does not discount the importance of the location of tourist experience. Rickly-Boyd argues that the geographic perspectives and the performance of a place, or attributes of a location, is an important contributor to existential authenticity (2013: 681). This idea is supported by a 2015 survey commissioned by HBO Entertainment which showed one in four adults $(\mathrm{n}=2000)$ held holiday aspirations at a place based on movie or TV locations (Gadd 2015). The survey showed the top three most aspirational destinations as: New Zealand Lord of the Rings; New York, USA Sex and the City; and The Causeway Coast and Glens, Northern Ireland Game of Thrones. While it should be noted that two of the top three destinations named in the HBO commissioned research feature the HBO-licensed television programs of Game of Thrones and Sex and the City and that the timing of study's release coincided with the release of season five of Game of Thrones, this nevertheless highlights the connections between tourism and popular culture.

Notably, all of these film and television locations are inspired by a work of literary fiction; with JRR Tolkien's Lord of the Rings Trilogy, Candace Bushnell's 1997 anthology of Sex and the City and the first novel in George RR Martin's 1996 fantasy series A Song of Ice and Fire being adopted as the namesake and story foundation for the television series Game of Thrones. The literary, televisual or cinematic representation of the narrative thus sets the agenda for a travel writer to continue the storytelling in a manner that connects a fictional storyline with an actual place. 


\section{Appropriating literature: by travel writers for the tourist gaze}

Each of the books referenced in this discussion were adapted to film or television before being appropriated by tourism communicators for destination promotional purposes. This in turn provided travel journalists with a story angle and creative licence for further modification. This appropriation is part of the creative process as travel communicators and journalists interpret a story in relation to the subject and then re-create it into a new story in their own style (Nicklas \& Lindar 2012: 6), which Hutcheon describes as a 'double process of interpreting and then creating something new' (2006: 20). Hornskov takes a more philosophical approach associating the concepts of appropriation and authenticity via the Latin-root of authenticity, auctor which means 'founder' or 'one who causes to grow': presenting authenticity as 'what comes out of - and continues to stand from - an original act of making' (2011: 107). This definition is relevant to my argument because it illustrates the creative, yet metamorphic process where the notion of original ownership/authorship is not ignored by the travel communicators, but rather material is dissected and recontextualised into a tourism setting.

This is demonstrated, for instance, by the way in which VisitBritain (2019) appropriated the character from A Bear Called Paddington, originally published in 1958 and the 2014 film adaptation Paddington, to put a new angle on attracting families to visit traditional London landmarks. The primarily-historical landmarks had not physically changed, nor did they feature new facilities (other than perhaps the addition of Paddington Bear merchandise outlets), but the story was used as a basis for developing a 'Pawprint Trail' around London and having young children engage in visits to sites, many youngsters may find boring, by spotting Paddington Bear statues and following Paddington's adventures. This aims to foster an intellectual and emotional connection between the story and the location as well as laying the foundation for positive memories of a happy family holiday.

When tourism experiences are built on a literary or popular culture foundation, it is often the fanciful destinations, compelling characters and plot that resonate and help readers/viewers make sense of the tourism offering and validate its authenticity (Yavuz 2014). While many people would consider a trip on the Jacobite Steam Train (2019) to be a lovely ride through the Scottish countryside, for Harry Potter enthusiasts it may be a lifedefining train ride on what a media release on the Visit Scotland website (2017) describes as the 'real-life Hogwarts Express' that connects their imagination with a genuine tourist activity.

Urry talks of the 'tourist gaze', as the expectations tourists have of a location because of the manner in which literature, film and television frame destinations of cultural, societal or historical significance (1991: 1). This 'gaze' is magnified when the story is shared or retold by other news or other popular media. One of the most common tools used by the tourism industry to motivate publicity is a media familiarisation (colloquially termed 'famil') - which allow journalists to sample a tourist destination usually following a purpose-built itinerary. For example, Visit Scotland (2017) launched a four-day 'magical' Harry Potter-inspired media itinerary where a journalist takes a four-day driving tour to visit filming locations and see where JK Rowling penned the 2007 novel The Deathly 
Hallows. Taking a more (f)actual approach to their media famils, a tourism region in Northern England, called The Lake District (2019), offers an 'In the footsteps of Beatrix Potter' itinerary that includes a visit to Beatrix Potter's House and tours around the countryside that inspired the writing and creation of characters like Peter Rabbit. The media familiarisation provides the journalist with the opportunity to verify facts by experiencing the tourism product and independently gathering information so they can weave their personal storytelling with reportage in order to navigate audiences between the familiar and the foreign in the quest for authenticity, wholeness and meaning in the tourism experience (Blanton 2012).

Like any tourist, the journalist's past understanding, feelings and attachment to the literary subject will guide their perception of the authenticity of the tourism product; but the paradigm will also take into account the views of the literary author, the imagery of film and television adaptations, the information provided by the tour operator as well as the journalist's personal introspection (Gruian 2012: 45). When a travel story is based on a journalist's actual experience, it frames the discourse of tourism authenticity because the story provides audiences with 'symbolic encrustations' of the literary legend thereby signifying and certifying the story subject as authentic (Culler 1981: 128). Consequently, according to Mansson, 'the tourist gaze becomes intertwined with the general consumption of media images as tourists consume mediated images of places' (2010:169) and the actualisation of a tourist destination meeting tourist expectations acts as a further marker of authenticity. Let us look at some examples of the power of mediation and appropriation of literary-induced tourism to illustrate how tourists are attracted to a tourist destination.

\section{The journey to Middle-Earth: New Zealand}

The promise of immersion in a fantasy storyline of dramatic mythical landscapes, colossal mountain ranges and troll-filled forests has driven media interest and tourism in New Zealand for nearly two decades. The rise of 'Tolkien Tourism' saw a 40 per cent increase in visitor numbers to New Zealand between 2000 and 2006, at least partly attributed to Peter Jackson's trilogy film adaptation of JRR Tolkien's Lord the Rings film trilogy shot in various locations around New Zealand (Handel 2013: 2).

Inspired by their literary and cinematic experiences, the previously unknown town of Matamata attracted more than 350,000 visitors a year (New Zealand Tourism) in what Beeton describes as 'a pilgrimage that provides tourists with a sense of belonging due to travelling alongside like-minded-souls' (2016: 88). Buchman, Moore and Fisher argue existential authenticity is strengthened and framed by shared experiences with attributes like communality and familiarity acting as a thread for travel communicators to connect New Zealand with the reverie of the story (2010: 230).

The New Zealand government and tourism authorities took extensive steps to leverage tourism spin-off opportunities by creating campaigns and tourism messaging indelibly aligned with the imagery and fantasy of Lord of the Rings (NZ Institute of Economic Research 2002). Croy (2004) attributes the association with the Lord of the Rings story as 
an inherent part of media coverage about New Zealand resulting in a positive image of New Zealand as an aspirational and inspirational tourism destination, with the story fuelling the basis of hundreds of media famils and subsequent publicity. This legacy is still evident today with Tourism New Zealand's media website (2019) featuring 83 film and television story angles to journalists, primarily based on the fiction of The Lord of the Rings and The Hobbit (as well as The Chronicles of Narnia, also filmed in New Zealand). These outnumber the 58 story leads about Maori Culture, 81 angles about New Zealand people, 34 stories about luxury and 74 generic New Zealand story pitches.

The story of The Lord of the Rings is embedded in the storytelling of New Zealand tourism much like JK Rowling's Harry Potter books and subsequent film adaptations have guided Great Britain's tourism narrative, where they have reworked aspects of the cultural identity of the destinations over an extended period of time. The multi-media(ted) approach, from book to film to news and feature stories, guarantees relevance and longevity beyond a campaign-based tourism approach to tourism communication (Lee 2012). 'The ability to walk in the footsteps of Potter (and his friends) or JK Rowling, to physically re-live and re-enact a moment in the narrative and its production, is but one failsafe against being forgotten and buried in the popular culture archives' (Lee 2012: 65).

\section{Romeo and Juliet in Verona}

According to the Bureau of Statistics of the Italian Veneto region (2017), 2.7 million people visit Verona each year. This includes many who take a personal pilgrimage to find, celebrate and grieve love through the story of Romeo and Juliet. Their visitation is motivated by Shakespeare's play as well as more than 30 film versions (Landazuri 2019). The ongoing mediatisation of this story angle by travel writers has seen Verona labelled as 'Italy's most romantic city' and home to Romeo and Juliet (Meacham 2016).

The hundreds of thousands of people who visit the tourist attraction of 'Juliet's house' and burial site each year want to believe that love is in the air, on the walls (where they scrawl their names), and between the bricks (where they stick their notes) and that rubbing a replica of a bronze statue of Juliet will grant them the power and magic of love (Weber \& Deutsch 2019). They are not bothered by the fact that Juliet's house was renovated in the 1930s to include a balcony so it looked more medieval and in line with the story, or that the statue of Juliet has been replaced because so many people rubbed it for good luck and leant up against it for photos that the arm snapped off (Bonadonna 2016). Many TripAdvisor reviews illustrate visitors are savvy that Juliet's house and burial site is not a factual historical site, more recognised as a 'reconstructed set for romantic people or teenagers in love' (Cerri 2019).

Tourism Verona (2018) enshrines the myth of Romeo and Juliet through the city's landscape and architecture and the promotion of tours where business operators keep the folklore alive in souvenir shops, themed cafes and tours incorporating experiences like staged wedding proposals on Juliet's balcony (Romeo and Juliet Guide 2019). The staging of a tourism experience (even if it includes historically incorrect features such as a $20^{\text {th }}$ 
century balcony on a $14^{\text {th }}$ century story), allows tourists to draw upon their cultural and personal interpretation to imagine themselves in the story; regardless of whether the story is fiction or non-fiction or even if the author even visited the location (Mathisen 2013; Tooke \& Baker 1996). Some sources, including the British Library suggest there is little to no evidence that William Shakespeare ever visited Verona (Dickson 2016). And while the romantic tragedy may have been appropriated by the tourism officials of Verona, even the self-appointed bastions of Juliet assert not only was it unlikely the Bard visited Verona but it is possible the story is appropriated from earlier literature:

The "Montecchi" (or "Monticoli") family and "Cappelletti (or "Dal Cappello") family really lived in thirteen-century Verona. The first person to write about the two rival houses was Dante Alighieri who in his Comedy (VI canto of Purgatorio)... The literary origin of the story of Romeo and Juliet dates back to 1530, when the Italian novelist Luigi Da Porto wrote his "Istoria novellamente ritrovata di due nobili amanti”. The plot was also used by Matteo Bandello some years later in his novel which had a huge success and was translated into French. This work was then taken and re-written in verses by Arthur Brooke. The poem was surely the main source of inspiration for Shakespeare, who wrote his "Romeo and Juliet" in 1596, which has become in the course of time a universal myth all over the world. (Juliet Club 'About Verona')

The tourist-act of attending the staging of one of Shakespeare's plays in Verona, participating in a literary festival or taking a literary walking tour could foster the perception of authenticity as an experience that has been constructed from fiction and yet evoking powerful feelings of connection at an existential level.

The literary-induced emotional connection transcends Eastern and Western cultures with the growing influx of tourists from China (Bureau of Statistics of the Veneto 2017) because Romeo and Juliet was the first of Shakespeare's works to be translated into Mandarin but also because the plot bears resemblance to a Chinese folk tale, The Butterfly Lovers (Smith 2018). This indicates that the historical evolution of the story and its ongoing adaptation are largely irrelevant factors in the perception of the authenticity of Verona's tourism offering. Instead, it can be argued that it falls to modern tourism interpretations to keep the angle relevant, evergreen and ageless for the tourist.

\section{More than a croc: Australian tourism experiences}

Tourism Australia adopted the story of Crocodile Dundee to promote international visitation in 1986. The tourism campaign was revived in 2018, when a television tourism commercial disguised as a sequel movie trailer aired during the American Super Bowl in February. This was followed by a series of online videos in October that took travellers on 'an exclusive behind the scene tours of the Dundee movie backlot showcasing the breadth of spectacular and unique experiences on offer across Australia' (Tourism Australia 2018a). As part of the campaign, Tourism Australia (2018a) invited travel media and influencers to participate in media familiarisation visits based on an upmarket semi-luxury 
itinerary that more closely represented the interests of the campaign's sponsors, Qantas, American Airlines and Wine Australia rather than the adventure-plot of the Crocodile Dundee movie. Nevertheless, the campaign results of more than 14,000 media articles and a 30 per cent increase in flight bookings from the USA to Australia (Tourism Australia $2018 b$ ) indicate the audience's mediated motivation to book a holiday.

Australian tourism richly illustrates how the extended timeliness of a literary-induced story angle can add a different layer to the history of a location. For example, the town of Echuca on the New South Wales and Victoria border still promotes itself on the basis of the 1958 novel by Nancy Cato and the 1983 television mini-series All The Rivers Run (Echuca Moama 2018). The small town of Bowen in Queensland's Whitsunday region claims Baz Luhrmann's movie Australia put them on the map in 2007 when the main street was transformed to replicate a scene of Darwin in the Northern Territory and the town's signage was temporarily changed from Bowen to 'Bowenwood' (Sydney Morning Herald 2007). The rolling countryside and fertile farming land near the town of Robertson in the Southern Highlands of New South Wales was the set for the movie Babe and inspired many city escapes from Sydney-siders (Entertainment Weekly 1996). And many a backpacker road trip has followed the colourful journey featured in The Adventures of Priscilla - The Queen of the Desert through Broken Hill, Coober Pedy, Kings Canyon and Alice Springs (McOwen 2009).

\section{Literary luau: Mark Twain in Hawaii}

In contrast with works of fiction, let us look at an example based on a factual account appropriated by tourism communicators in Hawaii. Samuel Langhorne Clemens, began his writing career in 1866 as a journalist for the Sacramento Union, writing under the pseudonym of Mark Twain. Before achieving fame, the author was tasked with writing a series of letters from the Sandwich Islands (later Hawaii), which later fuelled his books and international public speaking circuit of Roughing It and Letters from Hawaii.

Despite being prolifically quoted as a positive advocate for Hawaiian tourism, Twain's first impressions of the islands were not favourable. His fourth story for the Sacramento Union described the islands as 'rugged', 'useless' and 'barren' (Schmidt 2010). Mark Twain stayed in Hawaii for just over four months, primarily exploring the island from the back of a donkey with his initial letters being more of a narrative of adventure and discovery than a lyrical wax of the beauty of the landscape. However, over time, Twain's memories of his time in Hawaii became more descriptive and sentimental with warm memories. He recalls in a speech he gave in in 1889 in New York to honour the return of two baseball teams from a tour of the Pacific that included Honolulu:

For me the balmy airs are always blowing, its summer seas flashing in the sun; the pulsing of its surfbeat is in my ear; I can see its garlanded crags, its leaping cascades, its plumy palms drowsing by the shore, its remote summits floating like islands above the cloud wrack; I can feel the spirit of its wildland solitudes, I can hear the plash of 
its brooks, in my nostrils still lives the breath of flowers that perished twenty years ago. (Twain qtd in Fatout 2006: 246)

Twain's most famously attributed quote about Hawaii - 'the loveliest fleet of islands that lies anchored in any ocean' - was penned in a note to the Hawaiian Promotion Committee in 1908 thanking them for sending him a birthday present. This phrase set the scene for an advertising campaign captured in a 1926 holiday brochure (Stewart n.d.) and appears as a direct quote in around 19,500 Google search engine results (15 June 2019) thereby setting the scene for countless more modern-day travel stories by writers heading on a 'literary luau' to recreate tourism itineraries based on Mark Twain's stories (Smith 2016; Downes 2006). Horton argues that when it comes to promoting Hawaii, Mark Twain did as much as Captain Cook to make the islands known to the rest of the world (1996: 102). The New York Times reported: 'if you are looking for something to read to enrich your visit to Hawaii... What you want is Mark Twain' (Downes 2006).

The Hawaiian Promotion Committee, as it was known at the time before changing its name to the Hawaii Visitor and Convention Bureau appropriated the legend of Mark Twain to its marketing and promotional materials for more than 130 years. Over these years, many of Mark Twain's associations with Hawaii have been appropriated into tourism promotion, even if, for some public relations practitioners, a few facts may have eroded over time. Journalist Kim Steutermann Rogers (2016) was pitched a familiarisation trip that included staying in a historical Honolulu hotel on the basis that Mark Twain had apparently once entertained the 13-year old Hawaiian Princess Kaiulani there with stories and tall-tales. Unfortunately, as Steutermann Rogers points out, this was impossible given that Mark Twain visited Hawaii in 1866 and Princess Kaiulani was born in 1875 (ibid). Interestingly, the hotel still promotes Mark Twain as one of its famous past-guests, despite the nonexistence of the original building with the memory of Twain's stay being part of 'the rich history or its origin, deeply rooted sense of place and island hospitality' (Volcano House 2019).

\section{Conclusion}

Literary-induced storytelling, including that of film and television adaptations, lies at the core of many tourism communication strategies and is accepted by travel media as a credible angle to allow journalists to combine reportage with their own style of storytelling in a manner that resonates, sparks emotion and builds a connection with the audience. When literature is mediated and appropriated for tourism, as illustrated in the examples cited in this paper, the reader perceives this as a marker of authenticity. The process of journalists interpreting a literary-based perspective and then creating a new media story adds an evergreen element to this style of angle and continues to motivate tourists to relive and re-create the experience for themselves. Irrespective of the fiction or non-fiction basis of the literature, this powerful storytelling (or re-telling) has the capacity to engage and immerse audiences and strike an emotional connection thereby motivating their metamorphosis from passive audience-members into active tourists. 
The combination of a travel journalist's interpretation and imagination lays the foundation for them to create a seemingly authentic travel story steeped in existentialism where the audience's tourist experience is motivated by an emotional connection. The storytelling lures the audience to visit a destination and develop a stronger intellectual and physical bond due to the lived experience fuelling feelings of satisfaction. By the same token, if the physical product does not live up to the tourist's expectations of authenticity either as a shortfall in the subjective nature of constructive authenticity where the product doesn't match the literary description or it fails to evoke the feelings promised in the narrative, then both the mediated discourse and the true reality of the tourism product are brought into question.

Tourism authenticity, motivated by literature or its cinematic and televisual adaptations, is a balancing act with tourism communicators and journalists tasked with helping people find their own reality behind both the literary and mediated narrative while also articulating the characteristics of the tourism product/destination. This fine line between reportage and imagination-stoking storytelling is a key component for the delivery of authenticity in tourism.

\section{Works cited}

Arnould, E \& L Price 2000 'Authenticating acts and authoritative performances: Questing for self and community', in S Ratneshwar, D Mick \& C Huffman (eds) The why of consumption, Routledge, London: 935

Baker, B 2011 'Branding and the opportunities of movies: Australia', in N Morgan, A Pritchard \& R Pride (eds) Destination Brands, Butterworth-Heinemann, Oxford: 239-250:

http://www.sciencedirect.com/science/article/pii/B9780080969305100187 (accessed 1 February 2019)

Beeton, S 2016 Film-induced tourism, Channel View Publications, Buffalo. Available at: https://ebookcentral-proquest-com.ezproxy.library.uq.edu.au/lib/uql/detail.action?docID=4669088 (accessed 12 March 2019)

Blanton, C 2012 Travel writing:The self and the World, Routledge, London. Available at: https://ebookcentral-proquest-com.ezproxy.library.uq.edu.au/lib/uq1/detail.action?docID=672552\# (accessed 9 November 2018)

Bonadonna, E 2016 'Shakespeare In Verona: The Home Of Romeo \& Juliet', Culture Trip: https:/theculturetrip.com/europe/italy/articles/shakespeare-in-verona-the-home-of-romeo-juliet/ (accessed 9 November 2018)

Buchmann, A, K Moore \& D Fisher 2010 'Experiencing film tourism: authenticity and fellowship', Annals of Tourism Research 37, 1:229-248.

Bureau of Statistics of Veneto, 2017 'Tourist flows in the Veneto', Sistema Statistico Regionale: http://statistica.regione.veneto.it/ENG/banche_dati_economia_turismo.jsp (accessed 9 November 2018)

Cerri, M 2019 Review of Casa di Giulietta, TripAdvisor Australia, https://www.tripadvisor.com.au/ShowUserReviews-g187871-d246496-r649430257-Casa_di_GiuliettaVerona_Province_of_Verona_Veneto.html (accessed 9 November 2018)

Chaney, D 2002 'The Power of Metaphors in Tourism Theory', in S Coleman \& M Crang Tourism: between place and performance, Berghahn Books, New York 
Cohen, E 1988 'Authenticity and Commoditization in Tourism', Annals of Tourism Research 14, 3: 371386

Culler, J 1981 'Semiotics of Tourism', The American Journal of Semiotics 1 (1/2), 127-140. Available at: https://search-proquest-

com.ezproxy.library.uq.edu.au/docview/1297917181?rfr_id=info\%3Axri\%2Fsid\%3Aprimo (accessed 16 August 2018)

Croy, W 2004 'The Lord of the Rings, New Zealand and Tourism: Image Building with Film', Paper presented at CAUTHE 2004: Creating Tourism Knowledge conference, The University of Queensland, Brisbane, February. Available at:

https://www.researchgate.net/publication/238679456_The_Lord_of_the_Rings_New_Zealand_and_Touris m_Image_Building_with_Film (accessed 28 December 2018)

Dixon, A 2016 'Shakespeare’s Italian Journeys', Discovering Literature: Shakespeare \& Renaissance, British Library: https://www.bl.uk/shakespeare/articles/shakespeares-italian-journeys (accessed 19 September 2019)

Downes, L 2006 'Mark Twain's Hawaii’, New York Times (14 May):

https://www.nytimes.com/2006/05/14/travel/14twain.html (accessed 2 December 2018)

Echuca Moama 2018 'All the Rivers Run 35 ${ }^{\text {th }}$ Anniversary Celebration', Echuca Moama: The Murray's Living Legend: https://www.echucamoama.com/whats-on/events/event/226-all-the-rivers-run-35thanniversary-celebration_(accessed 12 February 2019)

Entertainment Weekly 1996 'Babe’s hometown', Entertainment: https://ew.com/article/1996/04/26/babeshometown/ (accessed 12 February 2019)

Erler, A 2012 'One Man's Authenticity is Another Man’s Betrayal: A Reply to Levy', Journal of Applied Philosophy 29, 3: 257-265

Fatout, P (ed) 2006 Mark Twain speaking, University of Iowa Press, Iowa City

Fletcher, N 2013 'Ethical Selves: A sketch for a theory of relational authenticity', Journal of Philosophy of Life 3, 1: 83-96

Gadd, M 2015 'Boom in holidays to places made famous by TV and film', Daily Mail, Australia: https://www.dailymail.co.uk/travel/travel_news/article-3134384/Boom-holidays-places-famous-TV-filmtourists-flocking-locations-Game-Thrones-Lord-Rings-Sex-City-Broadchurch.html (accessed 17 February 2019)

Gunn, CA 1997 Vacationscape: developing tourist areas, Taylor \& Francis, Washington

Gruian, A 2012 'Journalistic reportage vs. literary reportage. Diversion of reality towards propaganda during the proletcult time. Case study - F. Brunea-Fox', Revista Româna de Jurnalism si Comunicare 7, 3: 45-58. Available at: https://search-proquest-

com.ezproxy.library.uq.edu.au/docview/1350299351?rfr_id=info\%3Axri\%2Fsid\%3Aprimo (accessed 7 March 2019)

Handel, E 2013 The New Zealand Hobbit Crisis: How Warner Bros. bent a Government to its will and crushed an attempt to unionise The Hobbit. Los Angeles: Hollywood Analytics

Hartner, S 2005 'Authenticity', in CR Snyder \& SJ Lopez (eds) Handbook of Positive Psychology, Oxford University Press, New York: 382-394. Available at: ProQuest. New York, New York: Oxford University Press: $382-394$

Horskov, S 2011 'The authenticity challenge', in N Morgan, A Pritchard \& R Pride (eds) Destination Brands Butterworth-Heinemann, Oxford: 105-116. Available at: http://www.sciencedirect.com/science/article/pii/B9780080969305100084 (accessed 1 February 2019) 
Horton, T 1996 'Mark Twain in the Sandwich Islands', in B Dye (ed) Hawaii Chronicles: Island History from the Pages of Honolulu Magazine, University of Hawaii Press, Honolulu: 97-111

Hutcheon, L 2006 A Theory of Adaptation, Routledge, London. Available at: https://ebookcentral-proquestcom.ezproxy.library.uq.edu.au/lib/uql/detail.action?docID=291374 (accessed 13 February 2019)

Jacobite Steam Train 2018 'The Journey; the greatest railway journey in the world', West Coast Railways: https://www.westcoastrailways.co.uk/jacobite/jacobite-steam-train-details.cfm (accessed 2 February 2019)

Juliet Club, nd, http://www.julietclub.com/en/su-di-noi/ (accessed 5 February 2019)

Juliet Club, nd 'About Verona': http://www.julietclub.com/en/verona/ (accessed 5 February 2019)

Lake District, 2019 'In the footsteps of Beatrix Potter', VisitBritain:

https://www.visitbritain.com/au/en/media/itineraries (accessed 10 February 2019)

Landazuri, M 2019 'Romeo and Juliet (1968)', TCM: http://www.tcm.com/thismonth/article/191916\%7C0/Romeo-and-Juliet.html (accessed 15 June 2019)

Lee, C 2012 “"Have Magic, Will Travel”: Tourism and Harry Potter's United (Magical) Kingdom', Tourist Studies 12, 1: 52-69: https://doi.org/10.1177/1468797612438438 (accessed 10 February 2019)

MacCannell, D 1973 'Staged Authenticity: Arrangements of Social Space in Tourist Settings', American Journal of Sociology 79, 3: 589-603

Månsson, M 2010 'Negotiating authenticity at Rosslyn Chapel', in B Knudsen \& A Waade (eds) Reinvesting authenticity: Tourism, place and emotions, Channel View, Bristol

Mathisen, L 2013 Storytelling and story staging; Co-creating value in tourism, Doctoral thesis, Tromso University Business School, Norway. Available at: https://munin.uit.no/bitstream/handle/10037/6153/thesis.pdf?sequence=9\&isAllowed=y

Meacham, S 2016 'Verona: Home to Romeo and Juliet', Traveller: http:/www.traveller.com.au/veronahome-to-romeo-and-juliet-gonz4b (accessed 14 June 2019)

McOwan, G 2009 'Queens' land', The Guardian (14 March):

https://www.theguardian.com/travel/2009/mar/14/australia-desert-alice-springs (accessed 11 February 2019)

New Zealand Tourism, 2019 'Hobbiton, NZ - slice of Middle-earth', New Zealand:

https://media.newzealand.com/en/story-ideas/hobbiton,-nz-slice-of-middle-earth/ (accessed 8 December 2018)

New Zealand Tourism Media, 2019 'Story Ideas - Inspiring artcles and backgrounders about New Zealand', New Zealand: https://media.newzealand.com/en/story-ideas/ (accessed 8 December 2018)

Nicklas, P \& O Lindar (eds) 2012 Adaptation and Cultural Appropriation: Literature, Film, and the Arts, Walter De Gruyter, Berlin

NZ Institute of Economic Research 2002 Scoping the Lasting Effects of The Lord of the Rings: Report to the New Zealand Film Commission. Available at:

https://nzier.org.nz/static/media/filer_public/31/22/3122d46d-7d07-4777-a3a6-

8d3848384c32/scoping_the_lasting_effects_of_the_lotr.pdf(accessed 8 December 2018)

'On the Tracks of 007' 2019 'Join the Event of this Year', On the Tracks of 007:

https://www.onthetracksof007.com (accessed 24 February 2018)

Pine, B \& H Gilmore 2007 Authenticity: what consumers really want, Harvard Business School Press, Boston MA

Reijnders, S 2011 Places of the imagination: Media, tourism, culture, Ashgate, Farnham, Surrey: https://ebookcentral-proquest-com.ezproxy.library.uq.edu.au (accessed 9 January 2019) 
Rickly-Boyd, JM 2013 'Existential Authenticity: Place Matters', Tourism Geographies 15, 4: 680-686. Available at: https://doi.org/10.1080/14616688.2012.762691 (accessed 17 February 2019)

Riley, RW \& CS Van Doren 1992 'Movies as tourism promotion - a “pull” factor in a "push” location', Tourism Management 3: 267-74

Riley, RW, D Baker \& CS Van Doren 1998 'Movie induced tourism', Annals of Tourism Research 25, 4: 919-935

Romeo and Juliet Guide 2019 'Promise on Juliet's Balcony', Romeo and Juliet Guide: https://www.romeoandjulietguide.com/tour/tour-esclusivi/promise-on-juliets-balcony/ (accessed 5 February 2019)

Schmidt, B (ed) 2010 ‘The Sacramento Daily Union 1866', Twain Quotes: http://www.twainquotes.com/18660419u.html (accessed 7 February 2019)

Smith, D 2016 ‘A Literary Luau: Touring Hawai’i Island with Mark Twain’, Travel Mag:

https://www.travelmag.com/articles/touring-hawaii-with-mark-twain/ (accessed 18 January 2019)

Smith, O 2018 'The curious European destinations that Chinese tourists love visiting', The Telegraph (1 August): https://www.telegraph.co.uk/travel/destinations/europe/articles/top-destinations-for-chinesetourists/ (accessed 19 September 2019)

Steinbeck, J 1962 Travels with Charley: in search of America, The Viking Press, New York

Steutermann Rogers, K 2016 In Search of Mark Twain in Hawaii:

http://insearchofmarktwaininhawaii.blogspot.com (accessed 12 December 2018)

Stewart, D n.d. 'Honolulu: The Direct Way Service', Douglas Stewart Fine Books:

https:/douglasstewart.com.au/product/travellers-diary-paradise-isles-loveliest-fleet-islands-lies-anchoredocean/ (accessed 17 December 2018)

Sydney Morning Herald 2007 'Bowenwood keeps its cool as stars shine', Sydney Morning Herald (23 June): https://www.smh.com.au/entertainment/movies/bowenwood-keeps-its-cool-as-stars-shine-20070623gdqgd6.html (accessed 28 December 2018)

Traveller 2015 'New Zealand named world's top destination made famous by film and TV', Traveller: http://www.traveller.com.au/new-zealand-named-worlds-top-destination-made-famous-by-film-and-tvghy93a (accessed 2 February 2019)

Tooke, N \& M Baker 1996 'Seeing is believing: The effect of film on visitor numbers to screened locations', Tourism Management 17, 2: 87-94

Tourism Australia 2018a ‘Crocodile Dundee inspires \$36m American tourism push’, Tourism Australia: http://www.tourism.australia.com/en/about/our-campaigns/dundee.html (accessed 23 February 2019)

Tourism Australia 2018b 'Go backstage on the set of Dundee to discover the breadth of incredible experiences you can have on your next visit to Australia', Tourism Australia:

https://www.australia.com/en-us/campaigns/visit-the-set-of-dundee-super-bowl-ad/stunning-locationsfeatured-in-dundee.html (accessed 23 February 2019)

Tourism Australia 2019 'Making a Splash - Generating Publicity for Australia; A practical guide to working with the media', Tourism Australia:

http://www.tourism.australia.com/content/dam/assets/document/1/6/x/3/2/2002430.pdf (accessed 23 February 2019)

Tourism Verona 2018 'Verona city of love', Commune di Verona Tourism: http://www.turismoverona.eu/nqcontent.cfm?a_id=35631\&lang=en (accessed 12 February 2019)

Travel Weekly 2015 'New Zealand is the No. 1 Holiday Destination Made Famous by Film or Television', Travel Weekly: http://www.travelweekly.com.au/article/the-top-film-and-tv-tourism-destinations/ (accessed 21 February 2019) 
UNWTO 2018 'UNWTO Tourism Definitions', UNWTO:

http://publications.unwto.org/publication/UNWTO-Tourism-definitions (accessed 27 February 2019)

Urry, J 1990 The Tourist Gaze: Leisure and Travel in Contemporary Societies, Sage, Thousand Oaks CA

Visit Britain 2014 'The Paddington Trail', VisitBritain: https:/www.visitbritain.com/au/en/media/storyideas (accessed 4 March 2019)

Visit London 2017 'Paddington Bear day out for families', Visit London:

https://www.visitlondon.com/things-to-do/family-activities/paddington-bear-itinerary (accessed 4 March 2019)

Visit Scotland 2017 'Harry Potter tourism drive', Visit Scotland:

http://mediacentre.visitscotland.org/pressreleases/harry-potter-tourism-drive-2033286 (accessed 4 March 2019)

Voigts-Virchnow, E 2012 'Pride and Promiscuity and Zombies, or: Miss Austen Mashed Up in the Affinity Spaces of Participatory Culture', in P Nicklas \& O Lindar (eds) Adaptation and Cultural Appropriation: Literature, Film, and the Arts, Walter De Gruyter, Berlin

Volcano House 2019 'Our History: A Step Back In Time', Volcano House:

https://www.hawaiivolcanohouse.com/our-hotel/history/ (accessed 7 February 2019)

Wang, N 1999 'Rethinking authenticity in tourism experience', Annals of Tourism Research 26, 2: 349-370

Weber, C \& J Deutsch 2019 'In the Fair City of Verona, Star-Cross'd Lovers Want to Believe in La Casa di Giulietta', Smithsonian Magazine (14 February): https://www.smithsonianmag.com/smithsonianinstitution/fair-city-verona-star-crossed-lovers-want-believe-casa-giulietta-180971494/ (accessed 26 February 2019)

Yuvuz, M 2014 'Storytelling in Tourism: Opportunities for the Marketing and Branding of Adana Destination', Proceedings of the International Interdisciplinary Business-Economics Advancement Conference (IIBA), 16-19 July, Istanbul, Turkey 